\title{
The Urgency of Child Labor Rights Protection as an Influencer
}

\author{
Ai Permanasari \\ \{aipermanasari@gmail.com\} \\ Maranatha Christian University, Indonesia
}

\begin{abstract}
With the rampant activities of children in cyberspace, especially children who are used as influencers in representing certain products, there is a fear of economic exploitation of children, even by those closest to the child. The characteristics of the extent of limits and speed of digital online are difficult to answer by the current law, in terms of providing maximum protection for children working in this field. The research used in this research is the literature method, which is normative. The results show that the digital online business is growing rapidly, but the regulations are very few. Vulnerable children are easily exploited in this movement. Regulations related to child influencers can be formed with children's rights approach and the principle of child protection, while still paying attention to the online digital characteristic.
\end{abstract}

Keywords: Child Influencers; Child Labor; Child Rights

\section{Introduction}

Children, because of their young age and maturity, are unable to protect their own rights. Therefore, children are people who fall into the category of vulnerable groups.[1] Vulnerable groups in the term universal human rights can be defined as, certain groups of society who often experience discriminatory treatment, or need some special attention to protection from the State to prevent them from exploitation or from a dangerous environment. [2] In simple terms, it can be understood that vulnerable groups are groups that are easier or more at risk of having their rights violated, so that they are easier to become victims (both individually and in groups) because of their specificity / uniqueness, so they need more protection than the majority of people in society.

In the movement of the digital era 4.0 with the dominance of the Internet in our lives today (internet all things), children have an increasingly vulnerable position. The internet is not a safe place for children, according to the records of violence against children held by the National Commission on Children, during the January-June 2019 period, out of 420 cases of violence against children, 86 cases were caused by disclosure of children on social media. This means that about 30 percent of cases of violence in that period were triggered by the appearance of child in photos and videos uploaded on the internet. [3] However, today's children are digital natives, so it is difficult to separate them from the internet.

The internet today is a place for children to do everything a tool to interact and communicate, a place to play and do their hobbies, and a place to learn. The dependence of children on the internet is getting higher during the Covid 19 pandemic, where the government requires children to stay at home and learn from home. The internet, especially social media, 
is a place for children to express themselves, so there are many children's accounts that present children's abilities in dancing, singing, and covering all children's activities. These children have a huge following, so they become influencers for their followers.

An influencer in this case is someone who has the power to influence the attitudes and purchasing decisions of others because of their authority, knowledge, position or relationship with their audiences or followers (Definition of Influencer: Individuals who have the power to affect purchase decisions of others because of their (real) or perceived) authority, knowledge, position, or relationship). The existence of child influencers is used by businesses to market their products. There are still many conflicts in the categorization of child influencers, whether children really work or just run their hobbies and develop their talents.

The Manpower Act basically prohibits children from working, but with an exception if they are 13 to 15 years of age the child can work under certain conditions. Many of the child influencers we meet in online media are far below 13 years old, even when they were toddlers. It is clear that the Manpower Law has begun to stutter in addressing this disruption. The regulations regarding working children do not specifically regulate influencers, let alone accommodate the unique characteristics of the Internet. Regulations regarding child labor, such as working hours, a safe environment, and good positive effects on children, are difficult to translate accurately if they are related to the character of working in online media.

There is no government oversight of children who work as influencers, giving parent's unlimited power in determining the type of work, when children work, and including managing children's income. To prevent child exploitation, the Government must be present in supervising every business interaction and child labor on the Internet, in the form of a work permit / child activity policy, a mechanism for reporting child labor to comply with applicable regulations, and a mechanism for managing children's income so that it is properly used for welfare of the child.

The research method used in this research is the literature method, which is normative juridical. The results showed that with the uniqueness of children's work patterns on the internet, both from the child's age, working hours, and the work environment, the regulations that we have related to children are increasingly inaccessible, while there are real threats to children from the internet world and from parents themselves as guardians of the child. There is urgency for protection of children related to these activities. In this research, we could find the formulation of how child protection related to influencer activities can be designed.

\section{Children Work as Influencers}

"Child is meant to learn, not to earn" (James Davis). The quote is a slogan on the antichild labor campaign, which emphasizes that the main focus of children is learning not earning income or working. The Manpower Act basically prohibits children from working, although there are exceptions for jobs that develop children's talents and interests, as well as other restrictions. According to data presented by the Central Bureau of Statistics (BPS) in the 2018 criminal statistics, it shows that the highest rate of growth in crime is in terms of employing minors. [5] Entering 2020, the problem of child labor is getting more complex when the Covid-19 pandemic has a significant economic and social impact. Especially for those who are economically vulnerable.

[6] This has a domino effect on child labor and their families. Various health protocol policies to break the chain of spread of Covid-19, one of which requires children to learn from home (BDR). But on the other hand, this condition is used by the family as an opportunity so that children can be employed to increase family income. It is not easy to get past, children become a vulnerable group who then live their lives as child labor and enter the worst forms of 
child labor (WFCL). In ILO research, the impacts and risks for children during the pandemic were predicted to have setbacks for many years. One is that it will probably see an increase in child labor for the first time in 20 years. The pandemic has not only reversed the successful withdrawal of child labor that has been carried out so far, now even millions of children are at risk of returning to work at an early age or in dangerous conditions. [7]

Currently 30.1 percent of Indonesia's population or as many as 79.5 million are children where they are included in the digital native generation or the generation that was born when technology began to develop. [8] To facilitate their daily life, they always use gadgets and internet access. In the digital era where communication is mostly done with online media, social media has also developed which facilitates people to communicate with each other and share both about their pleasures and their personal lives. Online media can accommodate children's talents in any case, internet users become a very large audience to showcase children's talents. Children are the pride of the family to be the most attractive commodity to share online. It is proven that children have a very wide market, everything about children is very interesting and grabs the attention of social media users.

In fact, according to research, videos featuring children are more popular than other videos. [9] Many children become famous and become celebrities on social media with followers (followers) of tens of thousands and even millions. This phenomenon is captured by business people as a very potential marketing field. In fact, according to research, business people feel that marketing is more effective when hiring the services of internet celebrities (micro celebrity) to promote their products, rather than placing advertisements in conventional media. [10] Children who have a lot of followers have a big influence in influencing their followers in terms of inspiring or leading to use or not use a certain product. With this influence, children are called influencers or Kidfluencers.

Media Influencers shape the attitudes of their followers through blogs, tweets, photos and other social media uses. The influencer has access to a large and loyal following, who are actively following the influencer's movement. Influencers often monetize their social media presence by promoting products, services or marketing messages on their accounts. Social media influencers don't have to participate in paid promotions to be considered influencers, but many do. There are some of the biggest social platforms where influencers find success including Instagram, YouTube, Pinterest, Twitter, and Facebook. Influencers in this network usually make money by making posts about a specific product, service or event.

Many Kidfluencers are contracted by business people to promote their products, in the form of paid promotions and endorsements. By prioritizing the means of developing hobbies and talents, simultaneously generating money and involving contracts where children promote certain products, children as influencers will enter a gray area. When children make money, they are considered to be working, so that the regulation will be different from just running a hobby. With Kidfluencer income which is quite high, it makes parents diligently encourage their children to continue producing content that involves children, to be broadcast on the internet. A businessman contract with a child can be represented by parents, agencies, and some are directly involved with the child himself. Regardless of the validity of the contract, the child has entered into a work contract so that he is called a worker who receives wages or compensation for his work. According to Law Number 13 of 2003 concerning Manpower, a worker / laborer is any person who works and receives wages or other forms of remuneration.

Basically, children should not work, because children are physically and psychologically immature, still developing and need education, and are vulnerable to violence and exploitation. There are exceptions in the sense that children can work, but with certain limitations, related to restrictions on age, working hours, type of work and work environment. 
If these limits are violated, it can lead to violations of children's rights and crimes against children. The regulations on working children are based on the protection of children's rights. Children's rights are human rights that are recognized and protected by law (Article 52 paragraph (2) of the Republic of Indonesia Law No. 39 of 1999 on Human Rights) and the constitution, as stated in the 1945 Constitution of the Republic of Indonesia Article 28 B paragraph (2) where "Every child has the right to live, grow and develop and has the right to protection from violence and discrimination".

Related to the protection of child labor in the Republic of Indonesia Law no. 39 of 1999 are contained in Article 64 and Article 65. Article 64 stipulates that "every child has the right to receive protection from economic exploitation activities and any work that endangers him, so that it can interfere with his education, physical health, morals, social life, and his spiritual mentality" , whereas Article 65 stipulates that "every child has the right to obtain protection from activities of sexual exploitation and abuse, kidnapping, child trafficking, and from all forms of abuse of narcotics, psychotropic substances and other addictive substances".

Children's rights are also contained in the international conventions that we have ratified. Such as the Convention on the Rights of the Child, ILO Convention No. 138 of 1973 concerning Minimum Age for Admission to Work, and ILO Convention No. 182 of 1999 concerning the Prohibition and Immediate Action for the Elimination of the Worst Forms of Child Labor. Then from that all policies related to children and the implementation of child protection must be based on the four main principles of child protection contained in the KHA and also in Law Number 17 of 2016 concerning Stipulation of Government Regulations in Lieu of Law Number 1 of 2016 concerning the Second Amendment to the Law Number 23 of 2002 concerning Child Protection becomes a Law, namely the principle of non-discrimination, the best interests of the child, the right to life, survival and development, and respect for children's opinions.

It is necessary to spell out the rules for working children, so that we do not injure children's rights, let alone enter into child exploitation. Law No. 13 of 2003 concerning Manpower provides a limit that children can work if:

1) Light work and does not interfere with development and physical, mental and social health (for ages 13-15 years). Children must have written permission from a parent or guardian; There must be a work agreement between the entrepreneur and the parent or guardian; maximum working time of 3 (three) hours; done during the day and does not interfere with school time; ensure occupational safety and health; there is a clear working relationship; and receive wages in accordance with applicable regulations. Parental consent, work agreement and clear work relationship, can be exempted for children who work in their family businesses.

2) Employment within the framework of part of the education or training curriculum (for a minimum age of 14 years). Must be given clear instructions on how to carry out work and receive guidance and supervision in carrying out work. And given occupational safety and health protection.

3) Work to develop talents and interests. In accordance with Kepmenakertrans No. Kep. 115 / Men / VII / 2004 concerning Protection for Children Doing Work to Develop Talents and Interests, must meet the criteria that such work can be done by children from an early age, must be of interest to children, based on children's abilities, and the work adds creativity and must be in accordance with world of children. Furthermore, Article 5 paragraph (1) the Minister of Manpower and Transmigration Decree requires Entrepreneurs to: 
a. Make a written work agreement with the parent / guardian who represents the child and contains the conditions and conditions of work in accordance with the applicable provisions.

b. Employ outside of school time.

c. Fulfill the maximum working time requirements of 3 hours / day and 12 hours / week.

d. Involve parents / guardians at work locations to carry out direct supervision.

e. Providing a work place and environment that is free from the circulation and use of narcotics, gambling, liquor, prostitution and other similar things that adversely affect children's physical, mental and social development.

f. Provide rest facilities during waiting time

g. Implement occupational safety and health requirements

4) Children must not do work in the worst category of child labor, which includes:

a. Any work in the form of slavery or the like.

b. Any work that utilizes, provides or offers a child for prostitution, pornographic production, pornographic performances or gambling.

c. Any work that uses, provides or involves children for the production and trade of liquor, narcotics, psychotropic substances and other addictive substances and / or

d. All work that endangers the health, safety or morals of children. Described in Ministerial Decree No: KEP. 235 / MEN / 2003, namely:

1. Types of Work that Endanger the Health and Safety of Children:

- Work related to machinery, aircraft, installations and other equipment;

- Work carried out in hazardous work environments (physical hazards, biological hazards, chemical hazards);

- Work that contains certain dangerous characteristics and conditions

2. Types of Work that Endanger the Moral of Children

- Work in a bar, discotheque, karaoke, billiard business, cinema, massage parlor or any location that can be used as a place of prostitution;

- Work as a model for the promotion of alcohol, sexuality stimulants and / or cigarettes.

\section{Urgency of Protection for Children Working as Influencers}

“Children's rights must be preserved and protected, including on the internet, which must not be a lawless," (Bruno Studer, Member of Parliament of France behind the Kidfluencer Bill). Vulnerable children cannot be left without protection, Kidfluencer works on the internet where there are many threats to children's personal growth. In some cases, whether a Kidfluencer is paid or not is not a big problem compared to other threats to children such as manipulation of commercial parties, data theft, more explicitly threats of child pornography, pedophiles, bullying, child trafficking, bad digital images and other external threats. Internal threats are also a challenge where the nature of the work of a Kidfluencer, usually working from a private space, is usually regulated by parents or close people who act as guardians of the child in terms of making endorsement contracts and pay promotions in representing certain products. 
Parents do legally have power over the child as stated in Article 47 paragraph (1) of Law 16 of 2019 concerning Amendments to Law 1 of 1974 concerning Marriage, where children who have not reached the age of 18 (eighteen) years or have never been married under the control of their parents as long as they are not removed from power. In exercising power, parents have the right to control the care of their children, children do not have much space to participate in making decisions for their own interests. However, what must be considered is that what is meant by parental power is the power to carry out the obligations of parents towards their children.

Based on Article 45 paragraph (1) of the Marriage Law, parents are obliged to properly nurture and educate their children. In addition, based on Article 45 paragraph (2) of the Marriage Law, parents can represent children who are still in power regarding all legal actions inside and outside the court. The Child Protection Act also places an obligation on parents in fulfilling children's rights. Article 1-point a2 of the Child Protection Law emphasizes that children's rights are part of human rights that must be guaranteed, protected, and fulfilled by parents and others.

Article 1 point 4 of the Child Protection Law states that parents are the biological father / mother, or father and / or stepmother, father and / or adopted. Furthermore, parental participation in child protection is regulated in Article 20 of the Child Protection Law which states that the state, government, local government, community, family, and parents or guardians are obliged and responsible for the implementation of child protection. More deeply, Article 23 paragraph (1) also states that the State, Government, and Local Government guarantee the protection, maintenance and welfare of children by taking into account the rights and obligations of parents, guardians, or other people who are legally responsible for children.

So that the principle of the best interests of the child must become a priority in all decisions made by parents for children. As influencers, children can make quite a lot of money, and some parents even quit their jobs to become managers of their children, so that in that position the children are used as a source of family income. If that happens, appearing on the internet is no longer an option, but an obligation to continue producing, because if it stops, it will also stop family income. This is something that must be prevented, because supporting a family is not an obligation of children, but an obligation of parents. To ensure that the decision of parents to encourage their children to become influencers is to fulfill the principle of the best interests of the child, there must be certain standards that can be made. measure it. This cannot be left to parents alone, there must be state involvement in supervision so that children's rights are guaranteed and can be protected.

Kidfluencer as an artist in the internet world can fall into the category of working to develop children's talents and interests properly, which is the right of children who need to be given the opportunity to channel their talents and interests. In anticipation of avoiding exploitation of children in this field, the government has passed a policy in the form of Kepmenakertrans No. Kep. 115 / Men / VII / 2004 concerning Protection of Children Doing Work to Develop Talents and Interests. In Kepmenakertrans No. Kep. 115 / Men / VII / 2004 explained that work to develop talents and interests must meet the criteria that the work can be done by children from an early age, the work is of interest to the child, the work is based on the child's ability and the job adds creativity and is in accordance with the child's world.

In addition, in employing children to develop talents and interests who are less than 15 years old, employers are required to fulfill several requirements, one of which is to make a written work agreement with the parent / guardian who represents the child and contains the conditions and conditions of work in accordance with applicable regulations. But how to ensure that these regulations are implemented, and compatible with the way Kidfluencer 
works in cyberspace. Because if it is based on the regulations that apply when children as artists are trained as to develop children's interests and talents but do not conform to Article 71 of Law Number 13 Year 2003 concerning Manpower and Kepmenakertrans No. Kep. 115 / Men / VII / 2004 concerning Protection for Children Doing Work to Develop Talents and Interests, it can be categorized as economic exploitation of children which also means violating other statutory provisions as described above.

There should be special arrangements added to provide protection to Kidfluencer as a working child. This urgency was captured by the French state as a pioneer of Kidfluencer protection. On 26 June 2020, the French Senate unanimously validated the bill $n{ }^{\circ} 2519$ regulating the work of child influencers, which had already been approved by the National Assembly at the beginning of the year.

There are important things we can copy and adapt: [9]

a. There must be authorization from the government. In the new regulation, before children are involved in making videos for online material where there is a work relationship, they are required to obtain authorization from the government first. As part of the authorization process, parents of children will receive information about their child's rights and the consequences of releasing their child's pictures / videos on the internet.

b. Kidfluencerr working hours restrictions.

c. Children's financial arrangements. Where parents only get part of the child's income, not the whole. Kidfluencerr's earnings will be placed in a special account that can be accessed by the child when they grow up.

d. The platform's obligation to create a clear system for Kidfluencerrs and arrangements for protecting the right to be forgotten, where children can pull content about themselves, and at the child's request the platform must immediately delete the child's content.

The new rules will also apply to the so-called "gray zone", where the child is not in a working relationship, but spends a lot of time making videos or earning a significant income. Beyond a certain threshold regarding the number of videos produced, the cumulative duration of these videos, or the level of revenue generated by the videos, the child's parents must submit a statement to government authorities. Of course, there are time and income limitations that trigger the obligations of this declaration, and it is stipulated by more specific regulations. Based on the French law, Indonesia should have started drafting regulations protecting Kidfluencerrs.

In addition, there are things that must be considered in formulating protection for Kidfluencerr related to the unique characteristics of digital online. First, about children's privacy. Although it is acknowledged that the activities of "sharing" and "posting" have become a culture that cannot be avoided, it does not make us, especially children, lose their privacy. What happens is their privacy changes. But what matters most for children is that they feel they have agency, respect and dignity, which are the essence of privacy.

[10] So that anyone, both parents, and business people must prioritize this. When it comes to privacy, it is very important to consider carefully the long-term implications for children, because whatever we share and post will have an online digital footprint that is forever, widely visible and accessible. In the era of "Big Data" where our profiles are digitally captured and shaped, future employers and schools could Google and find posts about our children, about medical conditions, bed-wetting or inappropriate behavior. Controversial writing or posting views about other people or about an institution or belief, of course, will make our children difficult in the future. 
For this reason, it is ethical not to ask children to promote something that can damage their self-image. Child safety related to privacy is also very important to prevent children from violence or crime. So, there is no need to share the complete identity of the child, and you should avoid including the address and routine activities of the child. Businesses and owners of social media platforms are also legally required to keep personal information about their children private. For this reason, it is very important if the government makes regulations on child privacy and child labor protection in online media.

Second, protection against sexual and economic exploitation. Children are very vulnerable to exploitation, so protection must be provided. Business people and parents do not post pictures of children naked or dress them up sensually, even though the children are very young, because sexual predators can copy and share them. Ethically, it will also have a negative impact on the audience, which are mostly children as well. Economic exploitation can come from business people and parents. In order not to exploit children, one must obey child labor regulations and respect children's rights. The principle of best interest for children must be put forward.

Children have the right to have their voice heard to determine what they want to do, have the right to education, the right to rest and play, and activities as Kidfluencerr must be done because of the child's desire, not the ambition of the parents alone. The child's income from working as a Kidfluencerr must also be for the benefit of the child. There is no government supervision of children working as influencers, parents have unlimited power, including managing children's income. It is time for the government to make a regulation such as the "Coogan Law", which protects children's rights to the income generated by them.

\section{Closing}

Basically, children's participation as influencers must be voluntary, enjoyable and optional so that their rights are not violated in doing their job as Kidfluencer. Currently in Indonesia there is no law that specifically regulates children's activities as influencers, even though this work has been going on for a long time and has created many conflicts and loopholes, thereby increasing the risk of children experiencing exploitation. There is an urgency for protection for child influencers to be established immediately based on a child rights approach, general regulations on child labor, and child protection principles. Where in the end, what is mainly in the business focus of Kidfluencer is the welfare of the child itself, not only for the benefit of parents or other parties.

\section{References}

[1] M. V. B. T. \&. v. G. W. J. M. Sepuldeva, Human Rights Reference Handbook, Costa Rica: University of Peace, 2004.

[2] S. T. N, Human Rights of Vulneable \& Disadvantaged Groups, India: University of Pune Press, 2012.

[3] C. Indonesia, "Ekspose ANak di Media Sosial Berujung Kekerasan," CNN, 26 July 2019. [Online]. Available:

[4] https://www.cnnindonesia.com/gaya-hidup/20190724181156-284-415197/ekspos-anak-di-media-s osial-berujungkekerasan. [Accessed 10 February 2021].

[5] B. Dictionary, "Influencer," Business Dictionary, [Online]. Available: http://www.businessdictionary.com/definition/influencers.html. [Accessed 10 February 2021]. 
[6] S. S. P. d. Keamanan, "Statistik Kriminal 2018," Badan Pusat Statistika, Jakarta, 2018.

[7] K. P. A. Indonesia, "kpai.go.id," 03 December 2020. [Online]. Available: https://www.kpai.go.id/berita/expose-hasil-pengawasan-pekerja-anak-ta-2020-di-9-prov-20-kota-ka b. [Accessed 1002 2021].

[8] I. L. Organisation, "Pemantauan ILO: Covid 19 dan Dunia Kerja. Edisi ke empat 27 Mei," ILO, Indonesia, 2020.

[9] K. P. P. d. Anak, "kemenppa.go.id," 08 Juli 2020. [Online]. Available: https://www.kemenpppa.go.id/index.php/page/read/29/2776/ajari-anak-menjaga-privasi-di-mediasosial. [Accessed 1002 2021].

[10] Reuters, "cnnindonesia.com," Reuters, 2019. [Online]. Available: www.cnnindonesia.com. [Accessed 10 February 2021].

[11] D. Weinswig, "www.forbes.com.," forbes, 2016. [Online]. Available: www.forbes.com. . [Accessed 10 February 2021].

[12] N. Boring, "www.loc.gov," 30 Octorber 2020. [Online]. Available:

[13] https://www.loc.gov/law/foreign-news/article/france-parliament-adopts-law-to-protect-child-influe ncers-on-social-media/. [Accessed 1002 2021].

[14] E. Saner, "theguardian.com," the guardian, 24 May 2018. [Online]. Available: Emine Saner, 2018, "Sharent Trap, Should Parents Put Their Children on Social Media Instagram", theguardian.com. https://www.theguardian.com/lifeandstyle/2018/may/24/sharent-trap-should-parents-put-their-chi ldren-on-social-media-instagram. [Accessed 10 February 2021]. 